\title{
Physicochemical properties and antioxidant activity of Tunisian date palm (Phoenix dactylifera L.) oil as affected by different extraction methods
} Wahid HERCHI $^{1 *}$, Habib KALLEL ${ }^{1}$, Sadok BOUKHCHINA ${ }^{1}$

\begin{abstract}
The chemical analysis of flesh and seed of date palm fruit (Kentichi) was evaluated. Carbohydrates were the predominant component in all studied date cultivars ( 78.69-83.46 g/100g dry matter), followed by moisture content ( 9.23-11.17\%), along with moderate amount of fat ( 0.56-7.10 g/100g dry matter), protein ( 2.16-2.80 g/100g dry matter), and ash ( 1.18-1.64 g/100 $\mathrm{g}$ dry matter). Some antioxidants (Ascorbic acid, total phenolic, total flavonoid, chlorophyll and carotenoids) were found in different values in both date fruit and seed. The physicochemical properties and antioxidant activity of both flesh and seed oil which was extracted using Hexane, Soxhlet and Modified Bligh-Dyer extraction methods were determined. The experimental results showed that temperature, different solvents and extraction time had significant effect on the yield of the date palm oil and physicochemical properties. Date Flesh oil showed an important free radical scavenging activity towards 1-1-diphenyl2-picrylhydrazyl (DPPH) free radical.
\end{abstract}

Keywords: seed; flesh; oil; total phenolic; DPPH.

\section{Introduction}

The date (Phoenix dactylifera L.) has always played an important part of the economic and social lives of the people of arid and semi arid regions of the world. Tunisia is considered to be one of the date producing countries; the number of these trees is estimated to be over 4 million and around 100,000 tons of dates are produced annually. The fruit of the date palm is composed of a fleshy pericarp and seed (Besbes et al., 2005). Date seeds may have extractible high value-added components. Seeds are a waste product of many industries based on the technological transformation of date fruits or on their biological transformation (Besbes et al., 2005). It is well known that the average weight of date seeds is about $10-15 \%$ of date weight (Al-Shahib \& Marshall, 2003). In Tunisia, the lipid fraction of date seeds could amount to over 1000 tons, assuming a mean proportion of $10 \%$ of seed in date fruits and $10 \%$ oil content of seeds. Some scientists have studied chemical characteristics and fatty acid composition of date seed oil. The chemical characteristics of seed oil from two Tunisian date cultivars were as follows: iodine number $\sim 45$, peroxide value $\sim 20$ and acid value 1.5 (Besbes et al., 2004). The major fatty acid found in date seed oil was oleic acid (Besbes et al., 2004). Besbes et al. (2004) reported that the oxidative stability of date seed oils was higher than that of most vegetable oils and comparable to that of olive oil. They can also be used in formulation of Sun UV protectors that provide protection against both UV-A and UV-B, which are responsible for cellular damage (Besbes et al., 2004). Regarding their specificities, date seed oils could be used in cosmetic, pharmaceutical and food products (Besbes et al., 2004).

The chemical composition of the date shows that the flesh is an important source of sugar ( $81-88 \%$, mainly fructose, glucose and sucrose), dietary fibre ( $\sim 5-8.5 \%)$ and small amounts of protein, fat, ash and polyphenol (Al-Farsi et al., 2005).
Thus, dates provide a good source of rapid energy and a good nutritional value, based on their dietary fibre (DF) contents. DF has important therapeutic implications (e.g. for diabetes, obesity) and exhibits a protective effect (Al-Shahib \& Marshall, 2003). DF also shows some functional properties in the food industry, e.g. water-holding, oil-holding, and emulsifying (Montesinos-Herrero et al., 2006). The antioxidant activity of these foods can be attributed for their antioxidants compounds, such as ascorbic acid, vitamin $\mathrm{E}$ and carotenoids (Chaira et al., 2007), but also flavonoids and other phenolic constituents (Miguel et al., 2014; Chaira et al., 2007). The objectives of this study were to evaluate the proximate composition of flesh and seed from important date cultivars grown in Tunisia (Kentichi) and to compare the physicochemical characteristics and antioxidant activity of both seed and flesh oil obtained by three different extraction methods.

\section{Materials and methods}

\subsection{Chemicals and reagents}

All solvents and standards used in the experiments were purchased from Fisher Scientific Company (Ottawa, Ontario, Canada).

\subsection{Samples}

Date palm fruit (Kentichi) were collected at "Tamr stage" (full ripeness) from the oasis of Tozeur (Tozeur, Tunisia). The seeds were isolated, washed and both flesh and seeds were further air dried at $50{ }^{\circ} \mathrm{C}$ and then stored at $\left(-20^{\circ} \mathrm{C}\right)$ until analysis and extraction. 


\subsection{Physical properties}

50 date fruits (Kentichi) were randomly selected. Selected samples were healthy and free from any injuries. Seed dimensions (length (L), width (W) and Thickness (T)) were carried out with a digital caliper to an accuracy of $0.1 \mathrm{~mm}$. Seed weight in grams were determined using an electrical balance. Geometric mean diameter (Dg), Arithmetic Mean diameter (Da), Surface area (S), Sphericity (Ø), Seed/fruit volume (V), Oblate spheroid $\left(\mathrm{V}_{\text {osp }}\right)$ and Ellipsoid shapes $\left(\mathrm{V}_{\text {ellip }}\right)$ values were found using the following formula (Calisir et al., 2005; Shahbazi \& Rahmati, 2013):

$$
\begin{aligned}
& \text { Dg }=\text { Geometric Mean diameter }=(\mathrm{L} \cdot \mathrm{W} \cdot \mathrm{T})^{1 / 3} \\
& \mathrm{Da}=\text { Arithmetic Mean diameter }(\mathrm{L}+\mathrm{W}+\mathrm{T}) / 3 \\
& \pi=3.14 \text { mathematical constant }(\mathrm{Pi}) . \\
& \mathrm{S}=\pi \mathrm{D}_{\mathrm{g}}^{2} \\
& \emptyset=(\mathrm{L} . \mathrm{W} \cdot \mathrm{T})^{0.333} / \mathrm{L} \\
& \mathrm{V}=\pi \mathrm{B}^{2} \mathrm{~L}^{2} / 6(2 \mathrm{~L}-\mathrm{B}) \text { Where } \mathrm{B}=(\mathrm{WT})^{0.5} . \\
& \mathrm{V}_{\text {osp }}=4 \pi / 3(\mathrm{~L} / 2)(\mathrm{W} / 2)^{2} \text { Oblate spheroid } \\
& \mathrm{V}_{\text {ellip }}=4 \pi / 3(\mathrm{~L} / 2)(\mathrm{W} / 2)(\mathrm{T} / 2) \text { Ellipsoid shapes }
\end{aligned}
$$

\subsection{Proximate composition}

The dry matters contents of both flesh and seeds were determined by drying in an oven at $105^{\circ} \mathrm{C}$ during 24 hours to constant weight (Association of Official Analytical Chemists, 1990). The crude protein contents were calculated from nitrogen contents ( $\mathrm{N}$ x 6.25) obtained using the Kjeldahl method by AOAC (Association of Official Analytical Chemists, 1990). The crude fat contents were determined by continuous extraction in a Soxhlet apparatus for 6 hours using petroleum ether as solvent (Association of Official Analytical Chemists, 1990). The total ash contents were determined by incinerating both flesh and seeds $(2 \mathrm{~g})$ in a furnace at $550^{\circ} \mathrm{C}$ for 6 hours, then weighing the residue after cooling to room temperature in a desiccator (Association of Official Analytical Chemists, 1990). The carbohydrate contents were determined by deference that is by deducting the mean values of other parameters that were determined from 100 . Therefore $\%$ carbohydrate $=100-(\%$ moisture $+\%$ crude protein $+\%$ crude fat $+\%$ ash). Vitamin C content was determined by application of the 2.6 dichloroindophenol volumetric method (Association of Official Analytical Chemists, 1990). The sample calorific value was estimated (in Kcal) by multiplying the percentage crude protein, crude lipid and carbohydrate by the recommended factor (4, 9 and 4.125 respectively) used in vegetable analysis (Hunt et al., 1987).

\subsection{Protein fractionation}

Protein fractions were isolated by sequentially extracting both flesh and seeds with different solvents according to the modified Osborne scheme, as described by Chavan et al. (2001): Samples ( $1 \mathrm{~g}$ ) were dispersed in $10 \mathrm{~mL}$ distilled water by stirring with a magnetic stirrer and extracted over 45 minutes periods at room temperature $\left(25^{\circ} \mathrm{C}\right)$. The suspension was then centrifuged at $5000 \mathrm{~g}$ for 15 minutes, and the resultant supernatant was filtered. The residues were re-extracted twice more with the same solvent and the recovered filtrates were combined and designated the "water-soluble fraction". The residue was then extracted successively with $0.5 \mathrm{M} \mathrm{NaCl}$ solution (pH 7.0), $70 \%(\mathrm{v} / \mathrm{v})$ ethanol at $65^{\circ} \mathrm{C}$ in a shaking water bath, and $0.1 \mathrm{M}$ sodium hydroxide in order to separate the total date proteins into albumin, globulin, prolamin and glutelin fractions, respectively. Filtrates containing the desired protein fractions were dialyzed against distilled water for 48 hours at $4{ }^{\circ} \mathrm{C}$ and separately lyophilized. The protein content of each fraction was determined by the micro-Kjeldahl procedure (Association of Official Analytical Chemists, 1984).

\subsection{Soxhlet extraction method}

Date seed oil and date flesh oil contents were determined by continuous extraction in a Soxhlet apparatus for 6 hours using petroleum ether as solvent (Association of Official Analytical Chemists, 1990).

\subsection{Hexane extraction method}

Date seed powder and date flesh powder $(100 \mathrm{~g})$ was placed in a dark flask and homogenized with $500 \mathrm{~mL}$ of hexane. After mixing for 4 hours in a shaker at a rate of $180 \mathrm{U} / \mathrm{min}$, the mixture was centrifuged at $1,000 \mathrm{~g}$ for 15 minutes at ambient temperature $\left(20^{\circ} \mathrm{C}\right)$. The supernatant was then filtered through Whatman No. 2 filter paper (Cheikh Rouhou et al., 2006).

\subsection{Modified Bligh-Dyer extraction method}

The total lipids were extracted by the method of Folch et al. (1957) modified by Bligh \& Dyer (1959). Date seed powder and date flesh $(50 \mathrm{~g})$ were washed with boiling water for 5 minutes to denature the phospholipases (Douce, 1964) and then crushed in a mortar with a mixture of $\mathrm{HCCl}_{3}-\mathrm{MeOH}(2: 1, \mathrm{~V} / \mathrm{V})$. The water of fixation was added and the homogenate was centrifuged at $3000 \mathrm{~g}$ for 15 minutes. The lower chloroformic phase containing the total lipids was kept and dried in a rotary evaporator at $40^{\circ} \mathrm{C}$.

\subsection{Physicochemical characteristics}

Determination of Saponification value (SV), Acid value (AV), Free fatty acids (FFA), Iodine value (IV), Peroxide value (PV), $p$-anisidine value ( $p$-AV), UV absorption characteristics $\left(\mathrm{K}_{232}\right.$ and $\left.\mathrm{K}_{270}\right)$, and unsaponifiable matter (UM) of the extracted oil was carried out by standard IUPAC methods for the analysis of fats and oils (Dieffenbacher \& Pocklington, 1987). The mean molecular mass (MMM) was estimated from the relationships (560/saponification value) $\times 100$ (Ajiwe et al., 1996). Oxidation value $(\mathrm{OV})$ was calculated from Holm's equation, $\mathrm{OV}=p-\mathrm{AV}+2$ $(\mathrm{PV})$, while theoretical flavor scores $(\mathrm{F})$ were obtained from equation $\mathrm{F}=7.7-0.35$ (OV) (List et al., 1974). Oxidative stability was evaluated by the Rancimat method (Gutierrez., 1989). Stability was expressed as the oxidation induction time (hours), measured with the Rancimat 743 apparatus (Metrohm Co., Basel, Switzerland), using an oil sample of $1 \mathrm{~g}$ warmed to $100^{\circ} \mathrm{C}$ and air flow of $10 \mathrm{l} / \mathrm{h}$. Cholesterol content was estimated using Liebermann-Burchard reagent. Standard cholesterol solution 
used was $1 \mathrm{mg} / \mathrm{mL}$ as stock solution. Liebermann-Burchard reagent was prepared with $7 \mathrm{~mL}$ concentrated sulfuric acid and $5 \mathrm{~mL}$ glacial acetic acid and was covered with black paper and kept in ice bucket in dark place.

\subsection{Total Chlorophylls and Carotenoids}

A $600 \mathrm{mg}$ sample of date seed/flesh oil was fully dissolved in $2 \mathrm{~mL}$ cyclohexane. Chlorophyll and carotenoid were determined calorimetrically following the method of MinguezMosquera et al. (1991). The maximum absorption at $670 \mathrm{~nm}$ is related to the chlorophyll fraction and at $470 \mathrm{~nm}$ is related to carotenoid fraction. The values of the coefficients of specific extinction applied were $\mathrm{E}_{0}=613$ for the pheophytin as a major component in the chlorophyll fraction and $\mathrm{E}_{0}=2,000$ for lutein as a major component in the carotenoid fraction. Thus the pigment contents were calculated as follows:

$$
\begin{aligned}
& \text { Chlorophyll }(\mathrm{mg} / \mathrm{kg})=\left(\mathrm{A}_{670} \times 10^{6}\right) /(613 \times 100 \times \mathrm{d}) \\
& \text { Carotenoid }(\mathrm{mg} / \mathrm{kg})=\left(\mathrm{A}_{470} \times 10^{6}\right) /(2,000 \times 100 \times \mathrm{d})
\end{aligned}
$$

Where $\mathrm{A}$ is the absorbance and $\mathrm{d}$ is the spectrophotometer cell thickness $(1 \mathrm{~cm})$. The data reported is based on oil weight ( $\mathrm{mg} / \mathrm{kg}$ date seed/flesh oil).

\subsection{Total phenols and flavonoids}

Total phenols and flavonoids in date seed/flesh oil were determined colorimetrically at $725 \mathrm{~nm}$ with the FolinCiocalteau reagent as previously done by Gutfinger (1981).

\subsection{Fuel properties}

Higher Heating Value (HHV), known as the gross calorific value or gross energy, represents the heat released by the oxidation of a fuel in air. The HHV is the amount of heat produced by the complete combustion of a unit quantity of fuel. The HHV of date seed oil was calculated from the iodine value (IV) and saponification value (SV) derived using the following formula adopted by Demirbas (1998)

$$
\mathrm{HHV}=49.43-(0.041 \times \mathrm{SV})-(0.015 \times \mathrm{IV})
$$

The cetane number of the oil was determined according to Bose (2009)

$$
\mathrm{CN}=46.3+5458 / \mathrm{SV}-0.225 \times \mathrm{IV}
$$

\subsection{DPPH radical-scavenging activity}

The DPPH free radical-scavenging activity of oil was measured using the method described by Gorinstein et al. (2004). A $0.1 \mathrm{mM}$ solution of DPPH in methanol was prepared. An aliquot of $0.2 \mathrm{~mL}$ of sample was added to $2.8 \mathrm{~mL}$ of this solution and kept in the dark for 30 minutes. The absorbance was immediately measured at $517 \mathrm{~nm}$. The ability to scavenge the DPPH radical was calculated with the following equation:

Inhibition percentage $=(I \%)=\left[\left(A_{0}-A_{1}\right) / A_{0}\right]$

Where $A_{0}$ is the absorbance of the control, $A_{1}$ is the absorbance in the presence of sample. All samples were analyzed in three replicates.

\subsection{Statistical analysis}

Statistical analysis was performed by using the Proc ANOVA in SAS (software version 8). All analyses were replicated three times for each sample.

\section{Results and discussion}

\subsection{Morphological properties of date fruit and date seed from Kentichi}

A summary of the physical and dimensional properties of studied date fruit and date seed is shown in Table 1. These properties were found at specific moisture contents about $11 \%$ and $9 \%$ wet basis for date fruit and date seed, respectively. As seen in Table 1, all properties which were considered in the current study were found to be statistically significant. This could be due to the different cell arrangements in the fruits and seeds. According to the results, the mean values of properties which were studied in this research (length, width, thickness, geometric mean diameter, thousand fruit- seed weight, volume) were $30.2 \mathrm{~mm}, 13.1 \mathrm{~mm}, 16.1 \mathrm{~mm}, 18.4 \mathrm{~mm}$, 5.833 and $2194.4 \mathrm{~mm}^{3}$, respectively for date fruit. Knowledge about physical properties of agricultural products and their relationships is necessary for the design of handling, sorting, processing and packaging systems. The weight of date fruit was $5.82 \mathrm{~g}$ whereas the weight of date seed was $0.84 \mathrm{~g}$. Using weight as the classification parameter is the most accurate method of automatic classification for more fruits. Among these properties, the dimensions, volume and weight are the most important ones in the design of grading system.

\subsection{Proximate chemical composition of date flesh and date seed from Kentichi}

Table 2 presents the average chemical composition of date flesh and date seed from Kentichi. Date flesh contained 11\% moisture. Concerning the crude lipid contents, this value was $0.56 \%$. The total protein content was $2.16 \%$ of dry matter and

Table 1. Physical properties of date fruit and date seed from Kentichi (standard deviation in parentheses).

\begin{tabular}{lcr}
\hline \multicolumn{1}{c}{ Properties } & Fruit & \multicolumn{1}{c}{ Seed } \\
\hline Length $(\mathrm{mm})$ & $30.2 \pm 1.0^{\mathrm{a}}$ & $22.1 \pm 0.8^{\mathrm{b}}$ \\
Width $(\mathrm{mm})$ & $13.1 \pm 0.6^{\mathrm{a}}$ & $6.5 \pm 0.4^{\mathrm{b}}$ \\
Thickness $(\mathrm{mm})$ & $16.1 \pm 0.8^{\mathrm{a}}$ & $6.2 \pm 0.5^{\mathrm{b}}$ \\
Diameter $(\mathrm{mm})$ & & \\
$\quad$ & $18.4 \pm 0.4^{\mathrm{a}}$ & $9.5 \pm 0.4^{\mathrm{b}}$ \\
$\quad \mathrm{Dg}$ & $19.8 \pm 0.6^{\mathrm{a}}$ & $11.6 \pm 0.5^{\mathrm{b}}$ \\
$\quad \mathrm{Da}$ & $5.82 \pm 0.20^{\mathrm{a}}$ & $0.84 \pm 0.12^{\mathrm{b}}$ \\
Weight $(\mathrm{g})$ & $5.833 \pm 0.35^{\mathrm{a}}$ & $0.849 \pm 0.14^{\mathrm{c}}$ \\
$\mathrm{W}_{\text {1000 }}$ thousand fruit- seed weight $(\mathrm{kg})$ & $168 \pm 3.0^{\mathrm{a}}$ & $168 \pm 3.0^{\mathrm{a}}$ \\
Count $($ Fruit - Seeds $/ \mathrm{kg})$ & $1063.6 \pm 12.8^{\mathrm{a}}$ & $283.5 \pm 6.2^{\mathrm{c}}$ \\
Surface Area $\left.(\mathrm{S})(\mathrm{mm})^{2}\right)$ & $0.60 \pm 0.16^{\mathrm{a}}$ & $0.42 \pm 0.10^{\mathrm{b}}$ \\
Sphericity $(\varnothing)$ & $2194.4 \pm 14.5^{\mathrm{a}}$ & $271.4 \pm 5.7^{\mathrm{c}}$ \\
Volume $\left.(\mathrm{V})(\mathrm{mm})^{3}\right)$ & $2713.4 \pm 20.4^{\mathrm{a}}$ & $488.7 \pm 3.8^{\mathrm{c}}$ \\
Oblate spheroid $\left(\mathrm{V}_{\text {osp }}\right)\left(\mathrm{mm}^{3}\right)$ & $3335.0 \pm 24.7^{\mathrm{a}}$ & $466.3 \pm 6.2^{\mathrm{c}}$ \\
Ellipsoid shapes $\left(\mathrm{V}_{\text {ellip }}\right)\left(\mathrm{mm}^{3}\right)$ &
\end{tabular}

Values given are the means of three replicates \pm standard deviation. Means with different letters $(\mathrm{a}-\mathrm{c})$ within a row are significantly different at $p \leq 0.05$. 
a comparable result was found by Borchani et al. (2010). The ash content in date flesh was $1.64 \%$. The total carbohydrates content was found in the range of $83.46 \%$. Chemical analysis of date flesh showed that the content of ascorbic acid was 8.40 $\mathrm{mg} / 100 \mathrm{~g}$. Osborne solubility-based protein fractionation data indicated that albumins ( $52 \%$ of the total soluble protein) were

Table 2. Proximate chemical composition of date flesh and date seed from Kentichi.

\begin{tabular}{lcc}
\hline \multicolumn{1}{c}{ DAF } & Fruit Flesh & Seed \\
\hline Moisture (\%) & $11.17 \pm 0.32^{\mathrm{a}}$ & $9.23 \pm 0.40^{\mathrm{b}}$ \\
Oils (\%) & $0.56 \pm 0.10^{\mathrm{a}}$ & $7.10 \pm 0.54^{\mathrm{c}}$ \\
Protein (\%) & $2.16 \pm 0.27^{\mathrm{a}}$ & $2.80 \pm 0.18^{\mathrm{a}}$ \\
Ash (\%) & $1.64 \pm 0.13^{\mathrm{a}} 1.18 \pm 0.20^{\mathrm{b}}$ & \\
Total carbohydrate (\%) & $83.46 \pm 0.89^{\mathrm{a}}$ & $78.69 \pm 0.60^{\mathrm{a}}$ \\
Ascorbic acid (mg/100 g) & $8.40 \pm 0.23^{\mathrm{a}}$ & $9.74 \pm 0.10^{\mathrm{a}}$ \\
Energy (Kcal/100 g) & $357.95 \pm 4.51^{\mathrm{a}}$ & $399.69 \pm 4.12^{\mathrm{b}}$ \\
Energy (KJ/100 g) & $1498.66 \pm 12.08^{\mathrm{a}}$ & $1673.42 \pm 14.46^{\mathrm{b}}$ \\
Osborn protein fraction & & \\
$\quad$ Albumins (\%) & $52 \pm 1.21^{\mathrm{a}}$ & $42 \pm 0.96^{\mathrm{b}}$ \\
$\quad$ Globulins (\%) & $8 \pm 0.10^{\mathrm{a}}$ & $13 \pm 0.18^{\mathrm{b}}$ \\
$\quad$ Prolamins (\%) & $26 \pm 1.85^{\mathrm{a}}$ & $28 \pm 1.34^{\mathrm{b}}$ \\
$\quad$ Glutelins (\%) & $14 \pm 0.22^{\mathrm{a}}$ & $16 \pm 0.14^{\mathrm{b}}$ \\
\hline
\end{tabular}

Values given are the means of three replicates \pm standard deviation. Means with different letters $(\mathrm{a}-\mathrm{c})$ within a row are significantly different at $p \leq 0.05$. the most dominant, followed by prolamins $(26 \%)$ and glutelins (14\%), and with a small quantity of globulins also observed (8\%). For date seed, the moisture content was $9.23 \%$. The fat, protein and ash were $7.10 \%, 2.80 \%$ and $1.18 \%$, respectively. The total carbohydrates in Kentichi seed were $78.69 \%$ and it is comparable to the results reported by Besbes et al. (2004).

\subsection{Effects of extraction on Physicochemical and Fuel properties of seed oil from Kentichi}

The data of Table 3 show the physicochemical characteristics and Fuel properties of date seed oils extracted with the Soxhlet, Modified Bligh-Dyer, and Hexane methods. Crude oil extracted from date seed using Soxhlet method had the highest yield (7.11\%) followed by Modified Bligh-Dryer (5.70\%) and Hexane extraction method (5.12\%), respectively. This may be certified to the high ability of the petroleum ether (compared to chloroform-methanol and hexane) to extract some of lipid components in date seed as well as extraction period (6 hours) comparing with other extraction methods (0.5-4 hours). The SV of the seed oils extracted with different solvents ranged from 190 to $198 \mathrm{mg} \mathrm{KOH} \mathrm{g}^{-1}$ oil. As reported by Akbar et al. (2009) high saponification value indicates that oils are normal triglycerides and very useful in production of liquid soap and shampoo industries. Therefore, the value obtained for date seed

Table 3. Physicochemical and Fuel properties of seed oil from Kentichi.

\begin{tabular}{|c|c|c|c|}
\hline \multirow{2}{*}{ Parameters } & \multicolumn{3}{|c|}{ Extraction methods } \\
\hline & Hexane & Soxhlet & Modified Bligh-Dyer \\
\hline Extraction period (min) & 240 & 360 & 30 \\
\hline Organic solvent used & Hexane & Petroleum ether & Chloroform/methanol \\
\hline Physical state at room temperature & Liquid & Liquid & Liquid \\
\hline FFA content $(\%)$ & $0.85 \pm 0.05^{\mathrm{a}}$ & $0.90 \pm 0.05^{\mathrm{a}}$ & $0.75 \pm 0.05^{\mathrm{b}}$ \\
\hline Iodine value ( $\mathrm{g}$ of $\mathrm{I}_{2} / 100 \mathrm{~g}$ oil $)$ & $55.13 \pm 0.30^{\mathrm{a}}$ & $54.60 \pm 0.26^{\mathrm{a}}$ & $59.27 \pm 0.32^{\mathrm{b}}$ \\
\hline Peroxide value (mequiv $\mathrm{O}_{2} / \mathrm{kg}$ oil) & $11.90 \pm 0.10^{\mathrm{a}}$ & $10.37 \pm 0.24^{\mathrm{b}}$ & $9.15 \pm 0.38^{c}$ \\
\hline$p$-Anisidine value & $3.10 \pm 0.10^{\mathrm{a}}$ & $3.50 \pm 0.10^{\mathrm{b}}$ & $2.55 \pm 0.10^{c}$ \\
\hline Oxidation value & $23.42 \pm 0.30^{\mathrm{a}}$ & $27.30 \pm 0.38^{\mathrm{b}}$ & $20.85 \pm 0.86^{\mathrm{a}}$ \\
\hline Oil Stability (h) & $23.4 \pm 0.18^{\mathrm{a}}$ & $23.1 \pm 0.20^{\mathrm{a}}$ & $24.5 \pm 0.10^{\mathrm{b}}$ \\
\hline Unsaponifiable matter (\% w/w) & $5.40 \pm 0.14^{\mathrm{a}}$ & $5.72 \pm 0.10^{\mathrm{a}}$ & $6.28 \pm 0.22^{\mathrm{b}}$ \\
\hline Triglyceride (\%) ${ }^{\mathrm{a}}$ & $93.75 \pm 0.80^{\mathrm{a}}$ & $93.38 \pm 0.85^{\mathrm{a}}$ & $92.97 \pm 0.64^{\mathrm{b}}$ \\
\hline Cholesterol (mg/100 g oil) & $11.70 \pm 2.88^{\mathrm{a}}$ & $11.70 \pm 2.88^{\mathrm{a}}$ & $8.30 \pm 2.88^{\mathrm{b}}$ \\
\hline Chlorophyll (mg/kg oil) & $2.18 \pm 0.26^{\mathrm{a}}$ & $2.10 \pm 0.11^{\mathrm{a}}$ & $2.45 \pm 0.35^{\mathrm{b}}$ \\
\hline Carotenoids (mg/kg oil) & $11.24 \pm 0.47^{\mathrm{a}}$ & $10.41 \pm 0.51^{\mathrm{b}}$ & $12.76 \pm 0.28^{c}$ \\
\hline Total Phenolic, as caffeic acid equivalents (mg/100 g oil) & $319 \pm 2.46^{\mathrm{a}}$ & $312 \pm 2.15^{\mathrm{a}}$ & $347 \pm 3.88^{\mathrm{b}}$ \\
\hline Total Flavonoids, as rutin equivalents $(\mathrm{mg} / 100 \mathrm{~g}$ oil) & $41 \pm 1.30^{\mathrm{a}}$ & $46 \pm 1.17^{\mathrm{b}}$ & $52 \pm 1.25^{\mathrm{b}}$ \\
\hline Fuel properties HHV $(\mathrm{MJ} / \mathrm{kg})$ & $40.48 \pm 2.40^{\mathrm{a}}$ & $40.69 \pm 2.66^{\mathrm{a}}$ & $40.75 \pm 2.15^{\mathrm{a}}$ \\
\hline Cetane number & $61.46 \pm 1.34^{\mathrm{a}}$ & $62.29 \pm 2.49^{\mathrm{a}}$ & $61.69 \pm 1.58^{\mathrm{a}}$ \\
\hline
\end{tabular}

${ }^{a}$ Triglyceride $(\%)=100-\{($ free fatty acid, \%) + (unsaponifiable matter, \%) $\}$. Values given are the means of three replicates \pm standard deviation. Means with different letters $(\mathrm{a}-\mathrm{c})$ within a row are significantly different at $p \leq 0.05$. 
oil in this study show that it has high potential for use in the production of liquid soap and shampoos. The acid value and FFA of date seed oil extracted with soxhlet are higher than those other oils. A low acidity value indicates that the stability of the oil extracted using the Modified Bligh-Dyer method was higher than those other oils. The iodine value of date seed oil extracted using the Modified Bligh-Dyer, is higher than those other oils. The relatively low iodine value is indicative of the presence of a lower unsaturated bonds number. The lowest PV was also found in the oil extracted by Modified Bligh-Dyer extraction method $(9.15 \mathrm{meq} / \mathrm{kg})$ followed by Soxhlet one $(10.37 \mathrm{meq} / \mathrm{kg})$. Date seed oil can be stored for a long time without deterioration, since oils become rancid when the peroxide value ranges from 20.0 to 40.0 meq.O2/kg oil (Onyeike \& Acheru, 2002). The $p$-Anisidine value ( $p$-AV) of the seed oils extracted with different solvents ranged from 2.55 to 3.50 anisidine units. The $p$-AV values suggest the presence of significant amounts of secondary oxidation products in the test oil samples. The OV (20.85-27.30) indicates that considerable oxidative activity might be due to either lipoxygenase or autoxidation (Zia-Ul-Haq et al., 2007). Although the equation was developed for soybean oil, the flavor scores $(-1.85$ to 0.40$)$ indicate that the oils from the test date variety would receive rather low acceptance as an edible oil without further refinement. The values are comparable to flavor score values reported for (Cicer arietinum L.) seed oil (-0.92 to 3.11) (Zia-Ul-Haq et al., 2007). The primary and secondary oxidation products of date seed oil extracted using soxhlet, were higher than those of the other two extraction methods. With respect to the absorbance at 232 and $272 \mathrm{~nm}$, date seed oil seemed to show lower oxidation (Zia-Ul-Haq et al., 2007). All oils have a higher oxidation induction time (23.1h-24.5h). The difference in the oxidation induction period was explained by the difference in the level of unsaturated fatty acids and total phenolic compounds content (Besbes et al., 2004). Like all vegetable oils, triglycerides fraction of date seed oil represented the major part of the lipid fraction (92.97\%-93.75\%). These proportions were slightly lower to those of Deglet Nour (97.26\%) and Allig (96.90\%) (Besbes et al., 2004). Unsaponifiable content (\% w/w), chlorophyll and carotenoids content showed the same profile. Cholesterol content follows the same order using different extraction methods. The average value of phenolics and flavonoids compound of the Modified Bligh-Dyer extraction method was slightly high $(347 \mathrm{mg} / 100 \mathrm{~g}$ oil and $52 \mathrm{mg} / 100 \mathrm{~g}$ oil, respectively) compared to the other extraction methods. These values are lower than the values found by Besbes et al. (2005) for Deglet Nour seed oil (526 mg/100 g) and higher for Allig seed oil (215 mg/100 g). The fuel properties shown in Table 3 indicated that there was no significant difference for $\mathrm{HHV}$ and the cetane number among the extraction methods. The HHV, which is one of the most important properties of a fuel, is the amount of heat released during the combustion of $1 \mathrm{~g}$ of fuel to produce $\mathrm{CO}_{2}$ and $\mathrm{H}_{2} \mathrm{O}$ at its initial temperature and pressure. The highest heating value (40.75 MJ/kg) was obtained from date seed oil extracted by Modified Bligh-Dyer extraction method and the lowest $(40.48 \mathrm{MJ} / \mathrm{kg})$ from date seed oil extracted by Hexane extraction method. The heating values are the same for most of the oils (39-40 MJ/kg) except for castor oil $(37.3 \mathrm{MJ} / \mathrm{kg})$. The cetane number $(\mathrm{CN})$ is one of the most commonly cited indicators of diesel fuel quality, especially the ignition quality (Bamgboye \& Hansen, 2008). The highest CN
(62.29) was obtained for oil extracted by soxhlet extraction method and the lowest (61.46) from date seed oil extracted by Hexane extraction method. In the USA, No. 2 diesel fuel usually has a $\mathrm{CN}$ between 40 and 45 (Aminul Islam et al., 2012). The values of $\mathrm{CN}$ of soybean oil-derived biodiesel ranged from 45 to 60 , whereas those of rapeseed oil-derived biofuel ranged from 48 to 61.2 (Bamgboye \& Hansen, 2008). Higher CNs are associated with greater combustibility, good ignition, and assist in easy engine starting, low temperature starting, low ignition pressures, and smooth operation with lower knocking characteristics (Aminul Islam et al., 2012).

\subsection{Effects of extraction on physicochemical parameters and antioxidant activity of flesh oil from Kentichi}

Table 4 shows the physicochemical characteristics of date flesh oil extracted with the Soxhlet, Modified Bligh-Dyer, and Hexane methods. Crude oil extracted from date flesh using Soxhlet method had the highest yield $(0.56 \%)$. The effects of the extraction method on the oil stability and acidity were apparent, from the differences in acid value, the peroxide value and oxidative stability index. The free fatty acid contents of the two oils were statistically different from each other. Such differences being related to the quality of the raw material as a result of the storage time and degradation of the oil due to heating during extraction (Pontis et al., 2014). The peroxide values observed were within the limit established by Codex Alimentarius Commission (2005) - FAO/OMS (max. 10 mequiv $\left.\mathrm{O}_{2} \mathrm{~kg}^{-1}\right)$. The Modified Bligh-Dyer extraction method reflected better conservation of date flesh oil with greater preservation of the natural antioxidants due to the lower operating temperature. The oxidation value of the date flesh oils extracted with different solvents ranged from 10.08 to 13.74 . The investigated extractions differed significantly with respect to theoretical flavor scores. The oxidative stability, which is considered high value, varied among the oils and was highest in date flesh oil extracted by Modified Bligh-Dyer extraction method (11.2 hours). The values for carotenoids found in this oil (11-13 mg/kg oil) confirmed the appearance of date flesh oil. The average values found for total phenolic of date flesh oil extracted by Hexane, Soxhlet and Modified Bligh-Dyer extraction methods were 273, 260 and $284 \mathrm{mg} / 100 \mathrm{~g}$ oil, respectively. Date flesh oil could be considered as a potential source of natural phenolic compounds. In addition to their contribution to the resistance of oil to oxidative rancidity and their participation in confering specific flavor to oil (Besbes et al., 2004), it is worthy mention that some authors report that phenols could have a positive effect in the prevention of coronary heart disease and cancer (Miguel et al., 2014). The highest flavonoids content was also found in the oil extracted by Modified Bligh-Dyer extraction method (38 mg/100 g oil) followed by Soxhlet one (34 mg/100 g oil). Flesh oil obtained was subjected to screening for its possible antioxidant activity with the DPPH radical-scavenging assay (Figure 1). Flesh oil demonstrated marked antioxidant activity in the DPPH radical-scavenging assay. The data obtained from the DPPH test showed that flesh oil have a good activity. Flesh oil extracted by Modified Bligh-Dyer extraction method exhibited the highest inhibition ratio $(64.23 \pm 3.16)$. It appears that antioxidant activity could be related to the high content of total phenolics and to flavonoids. Consumption of foods rich 
Table 4. Physicochemical properties of date flesh oil from Kentichi.

\begin{tabular}{|c|c|c|c|}
\hline \multirow{2}{*}{ Parameters } & \multicolumn{3}{|c|}{ Extraction methods } \\
\hline & Hexane & Soxhlet & Modified Bligh-Dyer \\
\hline Yield (\%) & $0.32 \pm 0.05^{\mathrm{a}}$ & $0.56 \pm 0.10^{\mathrm{b}}$ & $0.40 \pm 0.05^{\mathrm{a}}$ \\
\hline Extraction period (min) & 240 & 360 & 30 \\
\hline Color & Brown oil & Brown oil & Brown oil \\
\hline Organic solvent used & Hexane & Petroleum ether & Chloroform/methanol \\
\hline Physical state at room temperature & Liquid & Liquid & Liquid \\
\hline FFA content $(\%)$ & $1.74 \pm 0.05^{\mathrm{a}}$ & $1.16 \pm 0.05^{\mathrm{b}}$ & $0.80 \pm 0.05^{\mathrm{b}}$ \\
\hline Iodine value ( $\mathrm{g}$ of $\mathrm{I}_{2} / 100 \mathrm{~g}$ oil) & $62.35 \pm 0.14^{\mathrm{a}}$ & $60.76 \pm 0.10^{\mathrm{a}}$ & $57.38 \pm 0.20^{\mathrm{b}}$ \\
\hline Peroxide value (mequiv $\mathrm{O}_{2} / \mathrm{kg}$ oil) & $4.15 \pm 0.02^{\mathrm{a}}$ & $5.22 \pm 0.05^{\mathrm{a}}$ & $3.78 \pm 0.02^{\mathrm{b}}$ \\
\hline$p$-Anisidine value & $2.80 \pm 0.05^{\mathrm{a}}$ & $3.30 \pm 0.1^{\mathrm{b}}$ & $2.32 \pm 0.05^{\mathrm{a}}$ \\
\hline Oxidation value & $11.10 \pm 0.10^{\mathrm{a}}$ & $13.74 \pm 0.20^{\mathrm{b}}$ & $10.08 \pm 0.10^{\mathrm{a}}$ \\
\hline Mean molecular mass (MMM) & $283 \pm 0.30^{\mathrm{a}}$ & $289 \pm 0.45^{\mathrm{a}}$ & $295 \pm 0.22^{\mathrm{b}}$ \\
\hline Oil Stability (h) & $10.2 \pm 0.31^{\mathrm{a}}$ & $10.0 \pm 0.50^{\mathrm{a}}$ & $11.2 \pm 0.28^{\mathrm{b}}$ \\
\hline Unsaponifiable matter (\% w/w) & $5.12 \pm 0.20^{\mathrm{a}}$ & $5.64 \pm 0.24^{\mathrm{a}}$ & $6.25 \pm 0.15^{\mathrm{b}}$ \\
\hline Triglyceride $(\%)^{\mathrm{a}}$ & $95.18 \pm 0.52^{\mathrm{a}}$ & $95.06 \pm 0.37^{\mathrm{a}}$ & $94.95 \pm 0.35^{\mathrm{b}}$ \\
\hline Cholesterol (mg/100 g oil) & $6.70 \pm 2.88^{\mathrm{a}}$ & $8.30 \pm 2.88^{\mathrm{b}}$ & $6.70 \pm 2.88^{\mathrm{a}}$ \\
\hline Chlorophyll (mg/kg oil) & $1.30 \pm 0.39^{\mathrm{a}}$ & $1.11 \pm 0.20^{\mathrm{a}}$ & $1.67 \pm 0.52^{\mathrm{b}}$ \\
\hline Carotenoids (mg/kg oil) & $6.74 \pm 1.12^{\mathrm{a}}$ & $5.37 \pm 0.90^{\mathrm{b}}$ & $7.50 \pm 0.94^{\mathrm{a}}$ \\
\hline Total Phenolic, as caffeic acid equivalents (mg/100 g oil) & $273 \pm 3.10^{\mathrm{a}}$ & $260 \pm 3.75^{\mathrm{b}}$ & $284 \pm 4.16^{\mathrm{a}}$ \\
\hline Total Flavonoids, as rutin equivalents (mg/100 g oil) & $34 \pm 1.32^{\mathrm{a}}$ & $30 \pm 2.51^{\mathrm{a}}$ & $38 \pm 1.12^{\mathrm{b}}$ \\
\hline
\end{tabular}

${ }^{a}$ Triglyceride $(\%)=100-\{($ free fatty acid, \%) + (unsaponifiable matter, \%) $\}$. Values given are the means of three replicates \pm standard deviation. Means with different letters (a-c) within a row are significantly different at $p \leq 0.05$.

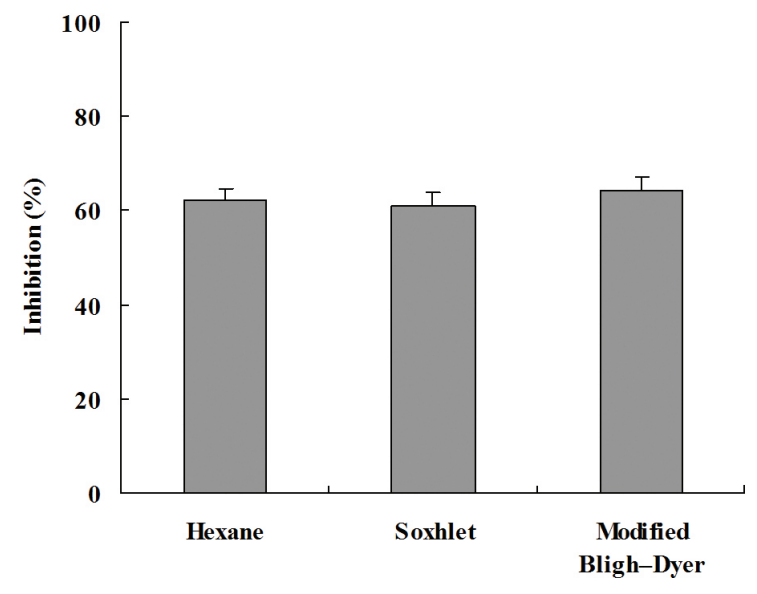

Figure 1. Antioxidant activity of oil from fruit flesh assessed by DPPH radical scavenging assay.

in natural antioxidants has been reported as being protective against certain types of cancer and may also reduce the risk of cardiovascular and cerebrovascular events (Miraliakbari \& Shahidi, 2008).

\section{Conclusion}

Comparing the three extraction methods, the oil extracted by Modified Bligh-Dyer extraction method presented lower extraction yields, but better values for oxidative stability, peroxide value and acidity, as well as higher pigment contents. The extracted oil was influenced by time, temperature and type of solvent. Date seed oils with good physicochemical properties will have potential to be biodiesel feedstocks. The antioxidant activity of the oils varies depending upon extraction methods.

\section{Acknowledgements}

We thank the Ministry of Scientific Research, Technology and Competence Development of Tunisia for financially supporting this investigation.

\section{References}

Ajiwe, V. I. E., Okeke, C. A., Agbo, H. U., Ogunleye, G. A., \& Ekwuozor, S. C. (1996). Extraction, characterization and industrial uses of velvet tamarind, physic-nut and nicker-nut seed oils. Bioresource Technology, 57(3), 297-299. http://dx.doi.org/10.1016/S09608524(96)00076-4

Akbar, E., Yaakob, Z., Kamarudin, S. K., Ismail, M., \& Salimon, J. (2009). Characteristic and composition of Jatropha Curcas oil seed from Malaysia and its potential as biodiesel feedstock. European Journal of Scientific Research, 29, 396-403.

Al-Farsi, M., Alasalvar, C., Morris, A., Baron, M., \& Shahidi, F. (2005). Comparison of antioxidant activity, anthocyanins, carotenoids, and phenolics of three native fresh and sun-dried date (Phoenix dactylifera L.) varieties grown in Oman. Journal of Agricultural and Food Chemistry, 53(19), 7592-7599. PMid:16159191. http://dx.doi. org/10.1021/jf050579q 
Al-Shahib, W., \& Marshall, R. J. (2003). The fruit of the date palm: its possible use as the best food for the future. International Journal of Food Science \& Technology, 54, 247-259.

Aminul Islam, A. K. M., Yaakob, Z., Anuar, N., Primandari, S. R. P., \& Osman, M. (2012). Physiochemical Properties of Jatropha curcas Seed Oil from Different Origins and Candidate Plus Plants (CPPs). Journal of the American Oil Chemists'Society, 89(2), 293-300. http:// dx.doi.org/10.1007/s11746-011-1908-7

Association of Official Analytical Chemists - AOAC. (1984). Official Methods of Analysis. 14th ed. Arlington: AOAC. Method 28.110.

Association of Official Analytical Chemists - AOAC. (1990). Official Methods of Analysis. 15th ed. Washington: AOAC.

Bamgboye, A. I., \& Hansen, A. C. (2008). Prediction of cetane number of biodiesel fuel from the fatty acid methyl ester (FAME) composition. International Agrophysics, 22, 21-29.

Besbes, S., Blecker, C., Deroanne, C., Lognay, G., Drira, N. E., \& Attia, H. (2005). Heating effects on some quality characteristics of date seed oil. Food Chemistry, 91(3), 469-476. http://dx.doi.org/10.1016/j. foodchem.2004.04.037

Besbes, S., Blecker, C., Deroanne, C., Lognay, G., Drira, N. E., \& Attia, H. (2004). Quality Characteristics and Oxidative Stability of Date Seed Oil during Storage. Food Science and Technology International, 10, 333-338. http://dx.doi.org/10.1177/1082013204047777

Bligh, E. G., \& Dyer, W. J. (1959). A rapid method of total lipid extraction and purification. Canadian Journal of Biochemistry and Physiology, 37(8), 911- 917. http://dx.doi.org/10.1139/o59-099

Borchani, C., Besbes, S., Blecker, C., Masmoudi, M., Baati, R., \& Attia, H. (2010). Chemical properties of 11 date cultivars and their corresponding fiber extracts. African Journal of Biotechnology, 9, 4096-4105.

Bose, P. K. Empirical approach for predicting the cetane number of biodiesel (2009). International Journal of Automotive Technology, 10(4), 421-429. http://dx.doi.org/10.1007/s12239-009-0048-7

Calisir, S., Ozcan, M., Haciseferogullari, H., \& Yildiz, M. U. (2005). A study on some physico- chemical properties of Turkey okra (Hibiscus esculenta L.) seeds. Journal of Food Engineering, 68(1), 73-78. http://dx.doi.org/10.1016/j.jfoodeng.2004.05.023

Chaira, N., Ferchichi, A., Mrabet, A. S., \& Sghairoun, M. (2007). Chemical composition of the flesh and the pit of date palm fruit and Radical scavenging activity of their extracts. Pakistan Journal of Biological Sciences, 10(13), 2202-2207. http://dx.doi.org/10.3923/ pjbs.2007.2202.2207

Chavan, U. D., Mckenzie, D. B., \& Shahidi, F. (2001). Protein classification of beach pea (Lathyrus maritimus L.). Food Chemistry, 75(2), 145-153. http://dx.doi.org/10.1016/S0308-8146(01)00122-4

Cheikh Rouhou, S., Hentati, B., Besbes, S., Blecker, C., Deroanne, C., \& Attia, H. (2006). Chemical composition and lipid fraction characteristics of Aleppo Pine (Pinus halepensis) mill seeds cultivated in Tunisia. Food Science and Technology International, 12(5), 407-416. http://dx.doi.org/10.1177/1082013206069910

Codex Alimentarius Commission - Codex. (2005). Codex standards for named vegetable oils: CODEX STAN 210 (revision 2005). Rome: $\mathrm{FAO} / \mathrm{WHO}$.

Demirbas, A. (1998). Fuel properties and calculation of higher heating values of vegetable oils. Fuel, 77(10), 1117-1120. http://dx.doi. org/10.1016/S0016-2361(97)00289-5

Dieffenbacher, A., \& Pocklington, W. D. (1987). Standard methods for the analysis of oils, fats and derivatives. International Union of Pure and Applied Chemistry. Oxford: Blackwell.

Douce, R. (1964). Identification et dosage de quelques glycérophosphosphatides dans des souches normales et tumorales de scosonères cultivés in vitro. Comptes Rendus de l'Académie des Sciences, 259, 3066-3068.

Folch, J., Lees, M., \& Sloane Stanley, G. M. (1957). A simple method for the isolation and purification of total lipids from animal tissues. The Journal of Biological Chemistry, 226, 497-509. PMid:13428781.

Gorinstein, S., Cvikrova, M., Machackova, I., Haruenkit, R., Park, Y. S., \& Jung, S. T. (2004). Characterization of antioxidant compounds in Jaffa sweeties and white grapefruits. Food Chemistry, 84(4), 503-510. http://dx.doi.org/10.1016/S0308-8146(03)00127-4

Gutfinger, T. (1981). Polyphenols in olive oils. Journal of the American Oil Chemists' Society, 58(11), 966-968. http://dx.doi.org/10.1007/ BF02659771

Gutierrez, F. (1989). Determination of virgin olive oils stability: Comparization between activated oxygen (AOM) and Rancimat Methods. Grasas y Aceites, 40, 1-5.

Hunt, C., Burn, P., \& Adamczuk, Z. C. (1987). Proximate composition and fat type of three popular take-away meals. International Journal of Food Science \& Technology, 22(6), 669-675. http://dx.doi. org/10.1111/j.1365-2621.1987.tb00535.x

List, G. R., Evans, C. D., Kwolek, W. F., Warner, K., Boundy, B. K., \& Cowan, J. C. (1974). Oxidation and quality of soybean oil: a preliminary study of the anisidine test. Journal of the American Oil Chemists' Society, 51(2), 17-21. http://dx.doi.org/10.1007/ BF02545207

Miguel, M. G., Nunes, S., Dandlen, S. A., Cavaco, A. M., \& Antunes, M. D. (2014). Phenols, flavonoids and antioxidant activity of aqueous and methanolic extracts of propolis (Apis mellifera L.) from Algarve, South Portugal. Food Science and Technology, 34, 16-23.

Minguez-Mosquera, M. I., Rejano-Navarro, L., Gandulrojas, B., Sanchez Gomez, A. H., \& Garrido-Fernandez, J. (1991). Colorpigment correlation in virgin olive oil. Journal of the American Oil Chemists' Society, 68(2), 332-336. http://dx.doi.org/10.1007/ BF02657688

Miraliakbari, H., \& Shahidi, F. (2008). Antioxidant activity of minor components of tree nut oils. Food Chemistry, 111(2), 421-427. http:// dx.doi.org/10.1016/j.foodchem.2008.04.008

Montesinos-Herrero, C., Cottell, D. C., O’Riordan, E. D., \& O'Sullivan, M. (2006). Partial replacement of fat by functional fibre in imitation cheese: Effects on rheology and microstructure. International Dairy Journal, 16(8), 910-919. http://dx.doi.org/10.1016/j. idairyj.2005.08.008

Onyeike, E. N., \& Acheru, G. N. (2002). Chemical composition of selected Nigerian oil seeds and physicochemical properties of the oil extracts. Food Chemistry, 77(4), 431-437. http://dx.doi.org/10.1016/ S0308-8146(01)00377-6

Pontis, J. A., Costa, L. A. M. A., Silva, S. J. R., \& Flach, A. (2014). Color, phenolic and flavonoid content, and antioxidant activity of honey from Roraima, Brazil. Food Science and Technology, 34, 69-73.

Shahbazi, F., \& Rahmati, S. (2013). Mass Modeling of Sweet Cherry (Prunus avium L.) Fruit with Some Physical Characteristics. Food and Nutrition Sciences, 4, 1-5. http://dx.doi.org/10.4236/ fns.2013.41001

Zia-Ul-Haq, M., Ahmad, M., Iqbal, S., Ahmad, S., \& Ali, H. (2007). Characterization and Compositional Studies of Oil from Seeds of Desi Chickpea (Cicer arietinum L.) Cultivars Grown in Pakistan. Journal of the American Oil Chemists' Society, 84(12), 1143-1148. http://dx.doi.org/10.1007/s11746-007-1136-3 